\title{
Tissue-specific regulation of rice molybdenum cofactor sulfurase gene in response to salt stress and $\mathrm{ABA}$
}

\author{
Ping-Min Huang $\cdot$ Jia-Yi Chen $\cdot$ Shu-Jen Wang
}

Received: 17 June 2008/Revised: 12 November 2008/Accepted: 5 December 2008/Published online: 22 January 2009

(C) Franciszek Górski Institute of Plant Physiology, Polish Academy of Sciences, Kraków 2009

\begin{abstract}
Molybdenum-containing aldehyde oxidase is a key enzyme for catalyzing the final step of abscisic acid (ABA) biosynthesis in plants. Sulfuration of the molybdenum cofactor (MoCo) is an essential step for activating aldehyde oxidase. The molybdenum cofactor sulfurase (MCSU) that transfers the sulfur ligand to aldehyde oxidase-bound MoCo is thus considered an important factor in regulating the $\mathrm{ABA}$ levels in plant tissues. In this study, we identified the rice $M C S U$ cDNA (OsMCSU), which is the first $M C S U$ gene cloned in monocot species. According to the functional domain analysis of the predicted amino acid sequence, the OsMCSU protein contains a Nifs domain at its $\mathrm{N}$-terminus and a MOSC domain at the $\mathrm{C}$-terminus. Expression of the $O s M C S U$ gene was up-regulated by salt stress in root tissues of rice seedlings, but this effect was not observed in leaf tissues. In roots, regulations of OsMCSU expressions could be mediated by both ABAdependent and ABA-independent signaling pathways under salt stress condition.
\end{abstract}

Keywords Abscisic acid .

Molybdenum cofactor sulfurase $\cdot$ Salt stress

$\begin{array}{ll}\text { Abbreviations } \\ \text { ABA } & \text { Abscisic acid } \\ \text { MCSU } & \text { Molybdenum cofactor sulfurase } \\ \text { MoCo } & \text { Molybdenum cofactor } \\ \text { MOSC } & \text { MCSU C-terminal conserved domain }\end{array}$

Communicated by G. Klobus.

P.-M. Huang · J.-Y. Chen · S.-J. Wang ( $ه)$

Department of Agronomy, National Taiwan University,

No. 1, Sect. 4, Roosevelt Rd, Taipei 106, Taiwan

e-mail: shujen@ntu.edu.tw
NCED 9-Cis-epoxycarotenoid dioxygenase

PLP Pyridoxal phosphate

\section{Introduction}

Salinity stress is a serious abiotic stress that results in limited plant growth and development due to the ionic toxin combined with osmotic stress. Plants respond to unfavorable environments mostly through the regulation of stress-related genes, which are usually involved in protection mechanisms, such as osmoprotectant and ion homeostasis production.

Several studies have previously identified abscisic acid (ABA)-mediated signaling as one of the transduction pathways that regulates the salt stress-responsive genes (Narusaka et al. 2003; Zhu et al. 2005). Changes in ABA content in various tissues under salinity conditions have been observed in many plant species (Zhu et al. 2005; Fricke et al. 2006). ABA is a molecule derived from carotenoids, and its biosynthesis involves oxidative cleavage of 9-cis-epoxycarotenoid to produce xanthoxin, which is catalyzed by 9-cis-epoxycarotenoid dioxygenase (NCED) in plastids (Schwartz et al. 1997). Xanthoxin is further modified to generate abscisic aldehyde in the cytosol via alcohol dehydrogenase (Gonzalez-Guzman et al. 2002); abscisic aldehyde is finally converted to ABA via aldehyde oxidase (Cutler and Krochko 1999). Thus, absence of aldehyde oxidase would result in ABA deficiency in plants (Bittner et al. 2001; Xiong et al. 2001; Sagi et al. 2002; Porch et al. 2006).

In addition to the concentration of available aldehyde oxidase, the activation of aldehyde oxidase is a key regulatory step for controlling the biosynthesis of ABA. The 
sulfur ligand-modified molybdenum cofactor (MoCo) that was bound on aldehyde oxidase plays an essential role in this activation process (reviewed by Schwarz and Mendel 2006). The sulfuration of MoCo is catalyzed by MoCo sulfurase (MCSU) (reviewed by Schwarz and Mendel 2006). mcsu mutants have been found in tomato and Arabidopsis, and mutation of the MCSU gene results in a decrease of aldehyde oxidase activity and deficiency in ABA (Marin and Marion-Poll 1997; Schwartz et al. 1997; Xiong et al. 2001). The MCSU proteins encoded by the Arabidopsis ABA3/LOS5 gene and tomato FLACCA gene are both composed of two functional domains: a NifS-like sulfurase domain at the N-terminus and a MCSU conserved domain (MOSC) at the C-terminus (Bittner et al. 2001). The NifS domain functions as cysteine sulfurase using pyridoxal phosphate (PLP) as a cofactor, and it transfers the sulfur from L-cysteine to target molecules and releases L-alanine (Zheng et al. 1993; Heidenreich et al. 2005). The conserved C-terminal is considered to function in the recognition of molybdenum enzymes (Bittner et al. 2001). Both the Arabidopsis los5-1 and los5-2 mutants contain mutations within the N-terminus of MCSU, while the aba3-1 and aba3-2 mutants contain mutation site at the N-terminal region of the MOSC domains (Xiong et al. 2001). The mutation in tomato flacca occurs at the C-terminus of the MCSU protein (Sagi et al. 2002). Previous studies of the mscu mutants showed that mutation at either the N-terminal or C-terminal portion of the protein disrupted MCSU function and reduced aldehyde oxidase activity and ABA content in plant tissues (Seo et al. 2000, 2004; Xiong et al. 2001; Sagi et al. 2002).

As mentioned above, MCSU is considered the key regulator for controlling $\mathrm{ABA}$ levels. In this study, we used RT-PCR to isolate the first $M C S U$ gene in monocot species, rice $O s M C S U$. We found that $O s M C S U$ expression is positively regulated by salt stress and ABA in the roots of rice seedlings but not in the leaves, indicating that the regulation of $M C S U$ genes in response to salt stress is tissue specific. Furthermore, the tissue-specific regulations of $M C S U$ gene by salinity are different between rice and Arabidopsis plants.

\section{Materials and methods}

Plant material and growth conditions

Rice (Oryza sativa L. cv. Tainung 67) seeds were sterilized in $1 \%$ sodium hypochlorite with Tween 20 for 15 min and subsequently washed three times with distilled $\mathrm{H}_{2} \mathrm{O}$. Seeds were then germinated at $37^{\circ} \mathrm{C}$ in the dark for 2 days, and then grown in a phytotron with half-strength of Kimura B nutrient solution (Chu and Lee 1989) at $30 / 25^{\circ} \mathrm{C}$ under natural daylight. For salt-stress treatments, threeleaf-stage seedlings were transferred to various concentrations of $\mathrm{NaCl}$ for $24 \mathrm{~h}$ prior to analysis of gene expression in roots and leaves of rice seedlings. To examine the effect of ABA on $O s M C S U$ gene expression, rice seedlings were cultured in half-strength Kimura $\mathrm{B}$ solution with $100 \mu \mathrm{M}$ ABA for $24 \mathrm{~h}$ prior to gene expression analysis in leaf and root samples. To determine whether salt stress-regulated $O s M C S U$ expression was ABA-dependent, rice seedlings were pre-cultured in a nutrient solutions containing $200 \mu \mathrm{M}$ fluridone (an ABA biosynthesis inhibitor) for $1 \mathrm{~h}$ prior to the subsequent 24-h treatment of $200 \mathrm{mM} \mathrm{NaCl}$ combined with $200 \mu \mathrm{M}$ fluridone. ABA content and OsMCSU expression in roots and leaves were then analyzed.

\section{RNA extraction}

Plant samples (100 mg) were homogenized in $1 \mathrm{~mL}$ Trizol reagent (Invitrogen, CA, USA) and centrifuged at $10,000 \times g$. The supernatant was treated with $0.2 \mathrm{~mL}$ chloroform, shaken for $15 \mathrm{~s}$, and incubated at room temperature for $3 \mathrm{~min}$. After centrifugation at $12,000 \times \mathrm{g}$ for $15 \mathrm{~min}$ at $4^{\circ} \mathrm{C}$, the upper layer was transferred to a new tube. RNA was precipitated with $0.5 \mathrm{~mL}$ isopropanol and incubated for $10 \mathrm{~min}$ at room temperature. After centrifugation, the pellet was dissolved in $0.2 \mathrm{~mL} \mathrm{H}_{2} \mathrm{O}$.

\section{Cloning and sequence analysis}

Total RNA extracted from leaves of rice seedlings was used as template for RT-PCR amplification of OsMCSU cDNA. The primers for RT-PCR amplification of the OsMCSU coding regions were designed according to the sequences derived from GenBank (AP003635). The primers used for RT-PCR were $O s M C S U$-F 5'-ATGGAGGTGAGCAAGG A-3' and $O s M C S U-\mathrm{R}$ 5'-TCATTCTGTGGAAGGGT- $3^{\prime}$. The RT-PCR amplified products were cloned into the pGEM-T Easy vector (Promega, WI, USA) and sequenced. Prediction of the amino acid sequence translated from $O s$ $M C S U$ cDNA was processed by the Wisconsin Genetics Computer Group (GCG) Software Package version 10.3. The functional domains in OsMCSU were determined by searching the conserved domain database v2.12 in NCBI's Entrez database system, and the specific motifs were derived by aligning the amino acid sequence with those of Arabidopsis ABA3 and tomato FLACCA (Xiong et al. 2001; Sagi et al. 2002). The multiple-sequence alignment was performed using the CLUSTALW software (http://www.ch. embnet.org/software/ClustalW.html). 
Quantitative real-time reverse transcriptase PCR

Total RNA (200 ng) was used as template for quantitative real-time RT-PCR analyses with the Brilliant SYBR Green QRT-PCR Master Mix (Stratagene, La Jolla, CA), and the PCR reactions were performed using a Multiplex 3000P Real-Time PCR System (Stratagene, La Jolla, CA). The gene-specific RT-PCR primers for OsMCSU were $5^{\prime}$-AC ATAGTCAGAGTGATTCAAGC-3' and 5'-TAACTTCC ATTGTCTTTTGC-3'. RT-PCR was carried out as follows: $50^{\circ} \mathrm{C}$ for $30 \mathrm{~min}$ and $95^{\circ} \mathrm{C}$ for $10 \mathrm{~min}$, followed by 40 cycles of $95^{\circ} \mathrm{C}$ for $1 \mathrm{~min}, 50^{\circ} \mathrm{C}$ for $1 \mathrm{~min}$, and $72^{\circ} \mathrm{C}$ for $1 \mathrm{~min}$. To accurately quantify relative expression levels of the genes, the $C_{T}$ value of $O S M C S U$ was normalized to the $C_{T}$ value of Actin. For all real-time RT-PCR analyses, three independent experiments were carried out, and the data are presented as mean $\pm \mathrm{SD}$.

\section{ABA content analysis}

After $\mathrm{NaCl}$ or fluridone treatment, the tissue samples were frozen with liquid nitrogen and stored at $-80^{\circ} \mathrm{C}$. The samples $(15 \mathrm{mg})$ were then extracted with $1.5 \mathrm{~mL}$ of $80 \%$ (v/v) methanol combined with $2 \%$ glacial acetic acid, and the ABA content was determined with the Phytodetek ABA test kit (Agdia Incorporated, IN, USA) using the competitive antibody binding method according to the manufacturer's protocol. The samples were loaded along with alkaline phosphatase-labeled ABA-tracers (ABA competitor) into wells that were coated with anti-ABA monoclonal antibodies. The levels of yellow color presented after the paranitrophenolphosphate (PNP) substrate and alkaline phosphatase reaction were inversely proportional to the ABA dosages in the samples. The intensity of the yellow color was correlated to the ABA concentration using a standard curve. Three replicates of experiments were processed and the final data were presented as mean $\pm \mathrm{SD}$.

\section{Results and discussion}

\section{Analysis of the cDNA of OsMCSU}

A sequence search of the National Center for Biotechnology Information (NCBI) Nucleotide database revealed the presence of several genes encoding MOSC domain-containing proteins in the rice genome. However, only one $M C S U$ gene (OsMCSU) was found. MCSU is also a single copy gene in both Arabidopsis and tomato (Xiong et al. 2001; Sagi et al. 2002). In this study, the cDNA fragment encoding the rice MCSU protein was amplified by RT-PCR (OsMCSU cDNA accession number: DQ855409), and this amplified cDNA encoded a protein of 824 amino acids. The predicted amino acid sequence of OsMCSU was 58.9 and $53 \%$ identical with that of the Arabidopsis and tomato MCSU proteins, the products of the ABA3 and FLACCA genes, respectively, and OsMCSU, ABA3, and FLACCA all share the same functional motifs (Fig. 1). The OsMCSU protein is composed of two major domains (Fig. 2). The Nterminal domain shows homology to bacterial Nifs proteins that could function as pyridoxal phosphate (PLP)-dependent sulfurtransferases for the desulfuration of cysteine to alanine. In addition to the PLP-binding domain, the $\mathrm{N}$ terminal region also contains a conserved cysteine motif (Fig. 2). The C-terminus of OsMCSU contains a MOSC domain, and the $\mathrm{N}$-terminal portion of this domain (MOSC_N) forms a beta barrel structure (Fig. 2). The function of the MOSC domain is still unclear, but is present in the C-terminal region of all MCSU proteins that have been identified thus far in humans, animals, and plants (Sagi et al. 2002). A previous research suggested that the MOSC domain could function to recognize the target molecular (Bittner et al. 2001).

Expression of $O s M C S U$ is regulated by salt stress and $\mathrm{ABA}$ in roots of rice seedlings

Roots are usually the primary plant organs that suffer in response to high salt problems in soil. To determine the effect of high salt concentrations on $O s M C S U$ expression in seedling roots, three-leaf-stage seedlings were treated with various concentrations of $\mathrm{NaCl}$. Although the effect of $50 \mathrm{mM} \mathrm{NaCl}$ on $O s M C S U$ gene expression was not significant, the OsMCSU mRNA levels were found to increase approximately fourfold and 3.7-fold in roots of seedlings treated with 100 and $200 \mathrm{mM} \mathrm{NaCl}$, respectively (Fig. 3a). However, no significant difference in the transcript levels of $O s M C S U$ in leaf tissues between unstressed and stressed seedlings (Fig. 3b). In contrast, the effect of $\mathrm{NaCl}$ on Arabidopsis MCSU gene (ABA3) expression in leaves was more significant than in roots when Arabidopsis seedlings were placed on filter paper saturated with $\mathrm{NaCl}$ (Barrero et al. 2006). These results implied that the effect of $\mathrm{NaCl}$ on $M C S U$ gene expression could differ among various plant species. Putative cis-elements on OsMCSU and AtABA3 promoter sequences have been characterized with the Database of Plant Cis-acting Regulatory DNA Elements (PLACE) (Higo et al. 1999), and the difference has been observed between the two promoters (data not shown). Therefore, the molecular mechanisms of $M C S U$ gene transcription could be different between rice and Arabidopsis. However, we could not rule out the possibility that the various sensitivities of $M C S U$ gene expressions in response to $\mathrm{NaCl}$ between rice and Arabidopsis tissues 
Fig. 1 Sequence alignment of rice $O s M C S U$ with the Arabidopsis and tomato homologs. The amino acids depicted in black box indicate fully identical residues; the residues shaded in grey indicate similarity. The putative PLPbinding and cysteine motifs are indicated with solid and dash underline, respectively.

Sequence accession numbers for OsMCSU, ABA3 and FLACCA are DQ855409, AY034895 and AY074788, respectively ABA 3 1 -..-MEAFLKEF GDYYGYPDGPKNIQE IRDTEFKRLDKGVVYLDHAGSTLYSELOMEY FLACCA 1 MNIESEKEQELKEFG SYGYANSPKNIDEIRATEFKRLND - TVYLDHAGATLYSESQMEA

OSMCSU 58 VLKDLASNVYGNPHSQSDSSMAA SDLVTAARHQVLKYFNASPREYKCIFTSGATAALKLV ABA 355 TFKDFT SNVFGNPHSQSDISSATSDLIADARHQVLEYFNASPEDY SCLFT S GATAALKLV FLACCA 60 VFKDLNSTLYGNPHSQSTCSLATEDIVGKARQQVLSFENASPREYSCIFT SGATAALKLV

OSMCSU 118 GECFPWSRESCYMYTMENHNSVLGIREYALSKGATVLAVDVEEGADLAKDNGSYSLYKIS ABA3 115 GETFPWTQD SNFIYTMENHNSVLGIREYALAQGA SACAVD IEEAANQP - - . - -GQLTNS FLACCA 120 GETFPWSSNSSFMYSMENHNSVLGIREYALSKGAAAFAVDIEDTHVGE- - . - - SESPQS

OSMCSU 178 RRTNQKRSKDVLSHNCQNGSLSDISGNNWNIFAFPSECNFSGQKFSZSLVKLIKEGK - - $\begin{array}{lll}\text { OSMCSU } & 178 & \text { RRTNQKRSKDVLSHNCQNGSLSDISGNNWNIFAFPSECNFSGQKFS SLLVKLIKEGK-- } \\ \text { ABA3 } & 169 \text { GPSIKVKHRAVQMRNTSKLQKEESRGNAYNLFAFPSECNFSGLRFNLDLVKLMKENTETV }\end{array}$ $\begin{array}{llll}\text { ABA } 3 & 169 & \text { GPSIRVKHRAVQMRNTSKLQKEESRGNAYNLFAFP SECNFSGLRFNLDLVKLMKENTETV } \\ \text { FLACCA } & 174 & - \text {-NLKLTQHHIQRRNEGGVLKEGMTGNTYNLFAFPSECNFSGRKFDPNLIKIIKEGSERI }\end{array}$

OsMCSU 235 -- IPLQQQGKWMVLIDAAKGCATEPPNLTVYPADFVVCSFYRIFGYPTGLGALIVKNEA ABA 3229 LQGSPFSK SRRMVLIDAAK GCATLP PDLSEYPADFVVL SFYKLFGYPT GL GALLVRNDA

FLACCA 232 LESSQYSRG-CWIVLIDAAKGCATNPPNLSMFRADFVVFSFYKLFGYPTGLGALIVRKDA Putative PLP binding motif

OSMCSU 292 ANLLNKTYFSGGTVAASIADIDFVQRRKNIEQVLEDGTISFLNIASLRHGFKIIEMLTTS

ABA3 289 AKLLKKTYFSGGTVAASIADIDFVKRRERVEEFFEDGSASFLSIAAIRH GFKLLKSLTPS

FLACCA 291 AKLMKKTYFSGGTVTAAIADVDFFKRREGVEEFFEDGTISFLSITAIQHGFK IINMLTTS

OSMCSU 352 AIERHTTSLATYVRNKMUDLKHSNE INVCTIYGQQY SKVEGLKMGPTITFNLKREDGSWF ABA 3349 AIWMHTTSLSIYVKKKLQALRH GNGAAVCVLY GSENLELSSHKSGPTVTFNLKR PDGSWF

FLACCA 351 SIFRHTTSIAAYVRNKLLALKHENGEFVCTLYG--.-LLSSEMGPTVSENMKRPDGTWY

OSMCSU 412 GYREVEKLASLFGIHLRTGCFCNPGACAKYLGLSHSDLVSNF EAGHVCWDDNDI INGKPT ABA3 409 GYLEVEKLASLSGIQLRTGCF CNP GACAKY LELSH SELR SNVEAGHICWDDNDVINGKPT FLACCA 406 GYREVEKLATLAGIQLRTGCFCNPGACAKYLGLSHLDLLSNIEAGHVCWDDRDILHGKPT Pütative cysteine- mo-tif

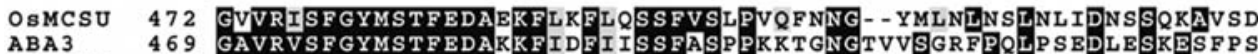

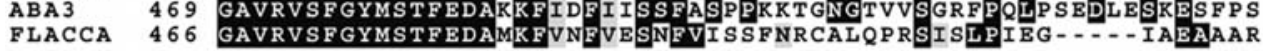

OSMCSU 530 IHLKSIIIYPVKSCQGFSVK SWPLTT GGLMYDREWLLQGSGGEILTQKKVPELGSTRTLI ABA 3529 HYLKS ITVYP IKSCA GF SVIRWPLCRTGLLHDREWMVQGLTGEILTQKKVPEMSLIKTFI

FLACCA 521 HFLTSITVYPIKSCAGFSVDQWPLTSTGLLHDREWIUKSTTGEILTQKKVPEMCYISTLI

OSMCSU 590 DLELGKLFIESPTRRDKLQLSZLES-ZADLSEEVDVFGQRYEVQSYDDRVNTWFSEAIGR ABA3 589 DLEEGLLSVESSRCEDKLHIRIIKSDSYNPR NDEFDSHANILENRNEE TRINRWFTNAIGR FLACCA 581 DLNLGKLFVESPRCKEKLQIELKSSSLVTERDEMDIQNHRYEVTSYNNEVDIWFSRAIDR

OSMCSU 649 PCTLVRCSSSKYRSCTYTGLRDRPCRDTQSKLNFVNEGQLLLISEESTSDLNSRLNSGKG ABA3 649 QCKLLRYSSST SKDCLNRNKSPGLCRDLESNINFANEAQFLLISEE SVADLNRRLEAKDE FLACCA 641 PCTLLRNSDSSHSCINKNGSPGMCRDVGARLNFVNEAQFLLISEESIKDLNSRLKSNGR

OSMCSU 709 D--CKQRLPVDAMRFHPNLVISGS SPYSEDNWKKLRIGEACFTSMGGCNRCQMINLHQDS ABA3 709 DYKRAHEKLN-PHRFRPNLVISGGEPYGEDKWKTVKIGDNHFTSLGGCNRCQMINISNEA FLACCA 701 RRNGGQAVQVGVMRFPNLVASSGEPYAEDGWSNINIGGKYEMSLGGCNRCQMININPEA

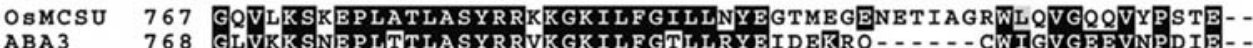

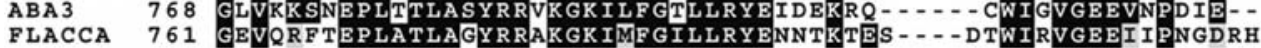

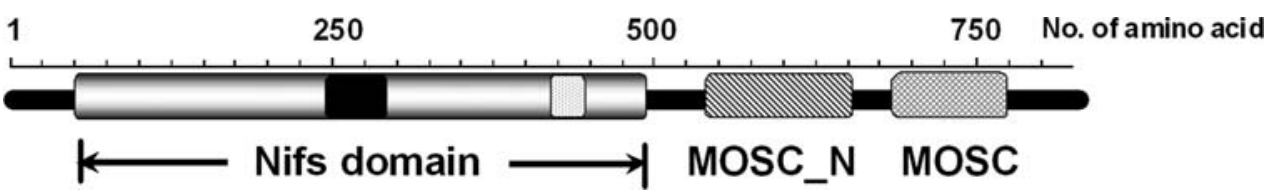

Fig. 2 Functional domains of the $O s M C S U$ protein product. The black box on Nifs domain indicates the putative PLP-binding motif, and the dotted box indicates the putative cysteine motif

was due to the different $\mathrm{NaCl}$-supplied processes within experiments.

Following, we observed the level of ABA in salt-stressed roots was increased as predicted (Fig. 4). On the other hand, although $\mathrm{NaCl}$-induced $O s M C S U$ expression was not observed in leaves of 24-h NaCl-treated seedlings (Fig. 3b), we previously observed an increase of ABA in leaf tissues of salt-stressed seedlings (Chen et al. 2007). 

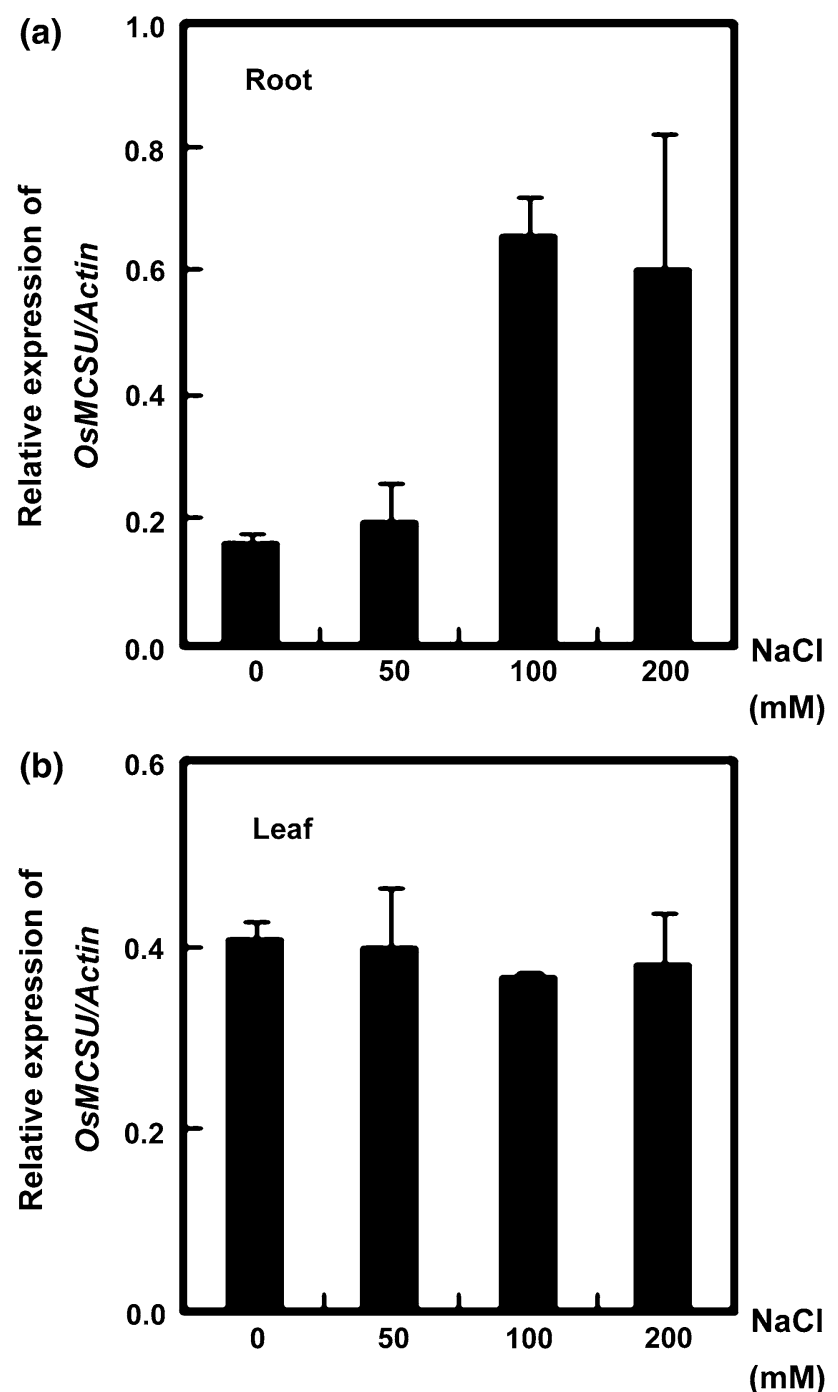

Fig. 3 Expression of $O s M C S U$ in salt-stressed rice seedlings. Transcript levels of $O s M C S U$ were measured in roots (a) and leaves (b) of 3-leaf-stage rice seedlings treated with 50,100 , or $200 \mathrm{mM} \mathrm{NaCl}$. Standard deviation is indicated with vertical bars

Since $O S M C S U$ is a single copy gene, the tissue-specific regulation of $O s M C S U$ in response to $\mathrm{NaCl}$ in roots compared to leaves of rice seedlings implied that the regulatory mechanisms of $\mathrm{NaCl}$-induced $\mathrm{ABA}$ biosynthesis in these tissues are distinct. Even there were many evidences to indicate that $\mathrm{ABA}$ could be synthesized in leaves under stress conditions for controlling turgor of guard cells (Pierce and Raschke 1980), it has also been reported that stomatal closure was due to sense the ABA transported from roots when the soil was dried but the leaf water level was remained (Blackman and Davies 1985). Thus, whether the $\mathrm{ABA}$ increased in leaves of salt-stressed rice seedlings in our works were transported from root tissues was needed to be further examined in the future. Besides, since the OsMCSU transcript level was not changed in salt-stressed seedling leaves, the possibilities caused ABA increase could be (1) changes of OsMCSU gene expression in response to $\mathrm{NaCl}$ were earlier than $24 \mathrm{~h}$; (2) post-transcriptional regulation of $O S M C S U$ could be an important factor to control ABA biosynthesis in leaf tissues.

As shown in Fig. 5, the levels of OsMCSU were enhanced by exogenous ABA $(100 \mu \mathrm{M})$ in roots, but this response was not detectable in leaves. $\mathrm{ABA}$ is considered as a stress hormone and a signal molecule involved in regulations of several environmental stresses-controlled gene expressions (Chandler and Robertson 1994). To determine the signal transduction of $\mathrm{NaCl}$-induced $\mathrm{Os}$ $M C S U$ expression in roots was mediated by $\mathrm{ABA}$ dependent or ABA-independent pathway, the inhibitor of ABA biosynthesis, fluridone, was applied with $\mathrm{NaCl}$ in seedling culture solution. As the data showed in Fig. 4, exogenous fluridone could repress ABA biosynthesis that was induced by $200 \mathrm{mM} \mathrm{NaCl}$. However, the level of OsMCSU expression in root tissues of $\mathrm{NaCl} /$ fluridone cotreated rice seedlings was still similar to that was detected in $\mathrm{NaCl}$ only-treated samples (Fig. 6). Therefore, we propose that the ABA-independent signal transduction could be a regulatory pathway for $\mathrm{NaCl}$-induced $O S M C S U$ expressions in rice root tissues. Previous studies indicated that the expressions of several ABA biosynthesis-related genes such as $N C E D 3, A A O 3$, and $A B A 1$ were enhanced by $\mathrm{NaCl}$ in ABA-deficient mutants (Xiong et al. 2002; Barrero et al. 2006). Together these results support the current concept that the expression of many abiotic stress-responsive genes are regulated by both ABA-dependent and ABA-independent mechanisms, and it also implies that the positive feedback regulation is an important factor in

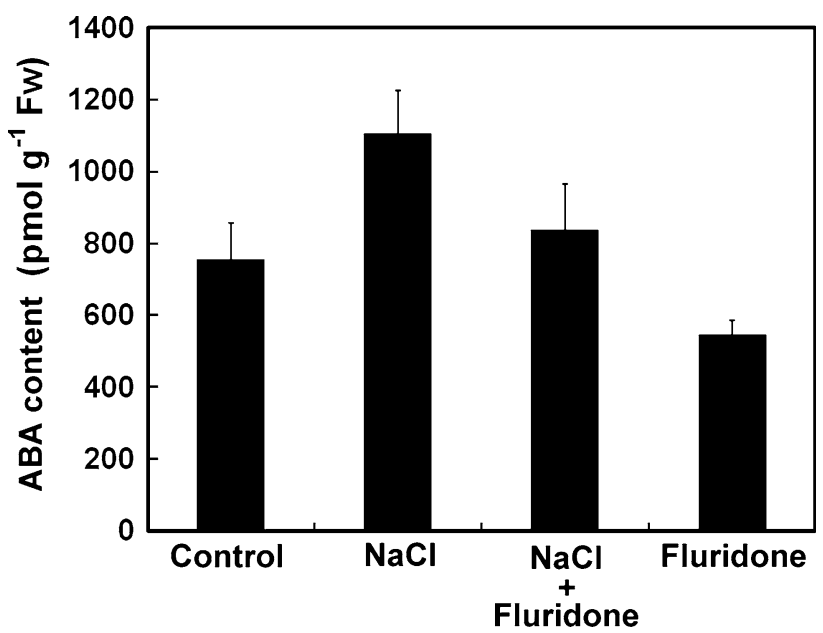

Fig. 4 Changes in ABA levels in root tissues under salt-stress conditions. ABA content in roots was analyzed after 3-leaf-stage rice seedlings were treated with $200 \mathrm{mM} \mathrm{NaCl}, 200 \mathrm{mM} \mathrm{NaCl}$ plus $200 \mu \mathrm{M}$ fluridone, or $200 \mu \mathrm{M}$ fluridone only 

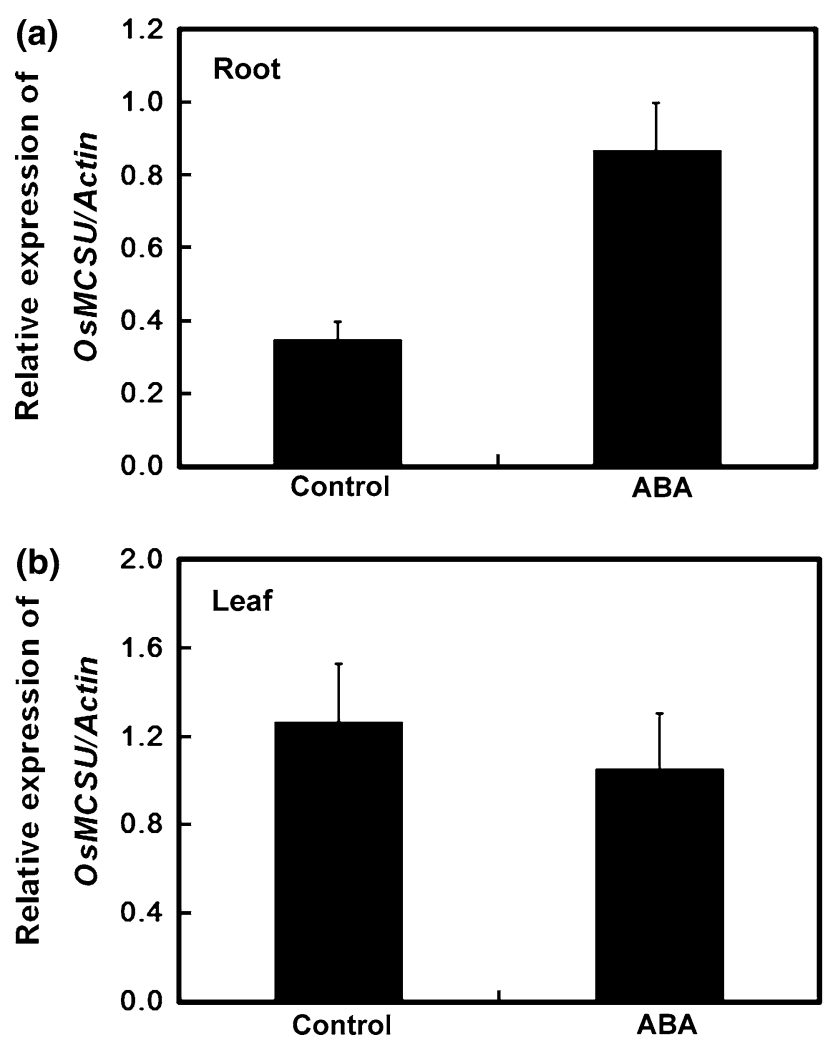

Fig. 5 Expression of $O s M C S U$ in ABA-treated rice seedlings. Transcript levels of $O s M C S U$ were determined in roots (a) and leaves (b) of 3-leaf-stage rice seedlings treated with $100 \mu \mathrm{M} \mathrm{ABA}$

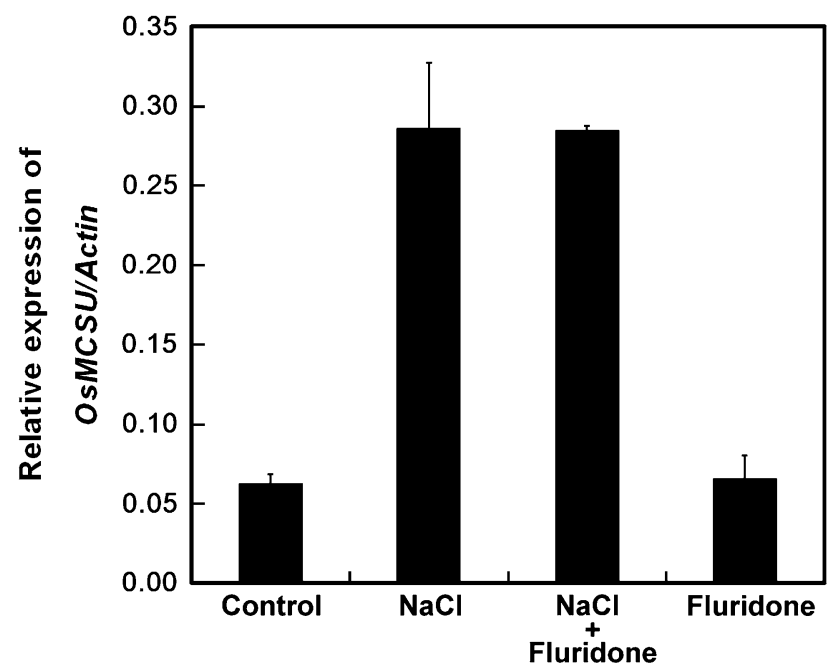

Fig. $6 \mathrm{ABA}$ effect on the $\mathrm{NaCl}$-induced $O s M C S U$ expression in roots of rice seedlings. Transcript levels of $O s M C S U$ were detected in roots of 3-leaf-stage rice seedlings treated with $200 \mathrm{mM} \mathrm{NaCl}, 200 \mathrm{mM}$ $\mathrm{NaCl}$ plus $200 \mu \mathrm{M}$ fluridone, or $200 \mu \mathrm{M}$ fluridone only

controlling ABA biosynthesis under unfavorable conditions (reviewed by Shinozaki et al. 2003).

In summary, our work showed that the rice OsMCSU gene was significantly up-regulated by $\mathrm{NaCl}$ in roots of seedlings, but was not responsive to salt stress in leaf tissues. The differential salt-stress response of OsMCSU between roots and leaves is in contrast to the response observed in dicotyledonous plant species such as Arabidopsis. Furthermore, the induction of OSMCSU expression in response to $\mathrm{NaCl}$ could be mediated by both ABAindependent pathway and ABA-mediated regulatory mechanism in roots of rice seedlings.

Acknowledgments We thank Dr. Chih-Wen Wu for providing rice seeds, and Tzu-Hsuan Kuo for assistance with ABA measurements. This work was financially supported by a research grant from the Council of Agriculture, Executive Yuan, Taiwan.

\section{References}

Barrero JM, Rodriguez PL, Quesada V, Piqueras P, Ponce MR, Micol JL (2006) Both abscisic acid (ABA)-dependent and ABAindependent pathways govern the induction of NCED3, AAO3 and ABA1 in response to salt stress. Plant Cell Environ 29:2000 2008. doi:10.1111/j.1365-3040.2006.01576.x

Bittner F, Oreb M, Mendel RR (2001) ABA3 is a molybdenum cofactor sulfurase required for activation of aldehyde oxidase and xanthine dehydrogenase in Arabidopsis thaliana. J Biol Chem 276:40381-40384. doi:10.1074/jbc.C100472200

Blackman PG, Davies WJ (1985) Root-to-shoot communication in maize plants of the effects of soil drying. J Exp Bot 36:39-48. doi:10.1093/jxb/36.1.39

Chandler PM, Robertson M (1994) Gene expression regulated by abscisic acid and its relation to stress tolerance. Annu Rev Plant Physiol Plant Mol Biol 45:113-141. doi:10.1146/annurev. pp.45.060194.000553

Chen HJ, Chen JY, Wang SJ (2007) Molecular regulation of starch accumulation in rice seedling leaves in response to salt stress. Acta Physiol Plant 30:135-142. doi:10.1007/s11738-007-0101-y

Chu C, Lee TM (1989) The relationship between ethylene biosynthesis and chilling tolerance in seedlings of rice (Oryza sativa L.). Bot Bull Acad Sin (Taiwan) 30:263-273

Cutler AJ, Krochko JE (1999) Formation and breakdown of ABA. Trends Plant Sci 4:472-478. doi:10.1016/S1360-1385(99) 01497-1

Fricke W, Akhiyarova G, Wei W, Alexandersson E, Miller A, Kjellbom PO, Richardson A, Wojciechowski T, Schreiber L, Veselov D, Kudoyarova G, Volkov V (2006) The short-term growth response to salt of the developing barley leaf. J Exp Bot 57:1079-1095. doi:10.1093/jxb/erj095

Gonzalez-Guzman M, Apostolova N, Belles JM, Barrero JM, Piqueras P, Ponce MR, Micol JL, Serrano R, Rodriguez PL (2002) The short-chain alcohol dehydrogenase ABA2 catalyzes the conversion of xanthoxin to abscisic aldehyde. Plant Cell 14:1833-1846. doi:10.1105/tpc.002477

Heidenreich T, Wollers S, Mendel RR, Bittner F (2005) Characterization of the NifS-like domain of ABA3 from Arabidopsis thaliana provides insight into the mechanism of molybdenum cofactor sulfuration. J Biol Chem 280:4213-4218. doi:10.1074/ jbc.M411195200

Higo K, Ugawa Y, Iwamoto M, Korenaga T (1999) Plant cis-acting regulatory DNA elements (PLACE) database: 1999. Nucleic Acids Res 27:297-300. doi:10.1093/nar/27.1.297

Marin A, Marion-Poll A (1997) Tomato flacca mutant is impaired in ABA aldehyde oxidase and xanthine dehydrogenase activities. Plant Physiol Biochem 35:369-372 
Narusaka Y, Nakashima K, Shinwari ZK, Sakuma Y, Furihata T, Abe H, Narusaka M, Shinozaki K, Yamaguchi-Shinozaki K (2003) Interaction between two cis-acting elements, ABRE and DRE, in ABA-dependent expression of Arabidopsis rd29A gene in response to dehydration and high-salinity stresses. Plant $\mathbf{J}$ 34:137-148. doi:10.1046/j.1365-313X.2003.01708.x

Pierce ML, Raschke K (1980) Correlation between loss of turgor and accumulation of abscisic acid in detached leaves. Planta 148:174-182. doi:10.1007/BF00386419

Porch TG, Tseung CW, Schmelz EA, Settles AM (2006) The maize Viviparous10/Viviparous13 locus encodes the Cnxl gene required for molybdenum cofactor biosynthesis. Plant J 45:250-263. doi:10.1111/j.1365-313X.2005.02621.x

Sagi M, Scazzocchio C, Fluhr R (2002) The absence of molybdenum cofactor sulfuration is the primary cause of the flacca phenotype in tomato plants. Plant $\mathrm{J}$ 31:305-317. doi:10.1046/j.1365313X.2002.01363.X

Schwartz SH, Leon-Kloosterziel KM, Koornneef M, Zeevaart JA (1997) Biochemical characterization of the aba2 and aba3 mutants in Arabidopsis thaliana. Plant Physiol 114:161-166. doi:10.1104/pp.114.1.161

Schwartz SH, Tan BC, Gage DA, Zeevaart JA, McCarty DR (1997) Specific oxidative cleavage of carotenoids by VP14 of maize. Science 276:1872-1874

Schwarz G, Mendel RR (2006) Molybdenum cofactor biosynthesis and molybdenum enzyme. Annu Rev Plant Biol 57:623-647. doi:10.1146/annurev.arplant.57.032905.105437

Seo M, Koiwai H, Akaba S, Komano T, Oritani T, Kamiya Y, Koshiba T (2000) Abscisic aldehyde oxidase in leaves of
Arabidopsis thaliana. Plant J 23:481-488. doi:10.1046/j.1365313x.2000.00812.x

Seo M, Aoki H, Koiwai H, Kamiya Y, Nambara E, Koshiba T (2004) Comparative studies on the Arabidopsis aldehyde oxidase (AAO) gene family revealed a major role of $A A O 3$ in ABA biosynthesis in seeds. Plant Cell Physiol 45:1694-1703. doi:10.1093/pcp/ pch198

Shinozaki K, Yamaguchi-Shinozaki K, Seki M (2003) Regulatory network of gene expression in the drought and cold stress responses. Curr Opin Plant Biol 6:410-417. doi:10.1016/ S1369-5266(03)00092-X

Xiong L, Ishitani M, Lee H, Zhu JK (2001) The Arabidopsis LOS5/ $A B A 3$ locus encodes a molybdenum cofactor sulfurase and modulates cold stress- and osmotic stress-responsive gene expression. Plant Cell 13:2063-2083

Xiong L, Lee H, Ishitani M, Zhu JK (2002) Regulation of osmotic stress-responsive gene expression by the LOS6/ABA1 locus in Arabidopsis. J Biol Chem 277:8588-8596. doi:10.1074/jbc. M109275200

Zheng L, White RH, Cash VL, Jack RF, Dean DR (1993) Cysteine desulfurase activity indicates a role for NIFS in metallocluster biosynthesis. Proc Natl Acad Sci USA 90:2754-2758. doi: 10.1073/pnas.90.7.2754

Zhu C, Schraut D, Hartung W, Schäffner AR (2005) Differential responses of maize MIP genes to salt stress and ABA. J Exp Bot 56:2971-2981. doi:10.1093/jxb/eri294 